\title{
Reuse of Electric Arc Furnace Slag as Filler for Nitrile Butadiene Rubber
}

\author{
ANNA GOBETTI ${ }^{1,3}$ GIOVANNA CORNACCHIA, ${ }^{2}$ \\ and GIORGIO RAMORINO ${ }^{1}$
}

\begin{abstract}
1.-Materials Science and Technology at Department of Mechanical and Industrial Engineering, University of Brescia, University of Brescia, Via Branze 38, 25123 Brescia, Italy. 2.-Metallurgy at Department of Mechanical and Industrial Engineering, University of Brescia, University of Brescia, Via Branze 38, 25123 Brescia, Italy. 3.—e-mail: a.gobetti@unibs.it
\end{abstract}

\begin{abstract}
This work shows an innovative application for electric arc furnace (EAF) slag: its use as a filler for nitrile butadiene rubber (NBR). Composites with various EAF slag contents were tested. It was found that the polymer matrix significantly reduces the leaching of slag (determined according to the standard CEN-EN 12457-2) incorporated in the NBR. The processability characteristics determined by the rheometric curves highlight that the EAF slag accelerates the crosslinking kinetics, reducing the production cycle time. Mechanical characterization demonstrated that EAF slag increases hardness and compression modulus. The ability to recover an imposed deformation quantified by the compression set is reduced as the EAF slag amount increases but remains below an acceptable value. It can be stated that in sealing systems, the EAF slag as a filler for NBR positively affects the compound properties. Moreover, NBR filled with EAF slag also has magnetic properties compared with standard rubber.
\end{abstract}

\section{INTRODUCTION}

Since the industrial revolution, our economies have developed a "take, make, consume and dispose of" growth model-a linear model based on the assumption that resources are abundant, available, and cheap to dispose of. Currently, the transition to a circular economy is essential for sustainable growth; in other words, better use of these resources can bring not only environmental but also economic benefits. The circular economy aims to maintain the added value in products for as long as possible while minimizing waste $^{1,2}$ or turning waste into a resource as part of 'closing the loop'. ${ }^{3}$ In this context, industrial symbiosis is the process by which wastes or by-products of an industrial process become the raw materials for another sector. ${ }^{4-6}$ The application of this concept allows materials to be used in different sustainable ways and contributes to the creation of a circular economy. Through a territorial

(Received June 10, 2021; accepted December 26, 2021; published online January 25, 2022) approach, industrial symbiosis involves traditionally independent industries in a business interaction process aimed to obtain competitive advantages deriving from the transfer of resources (by-products or production waste) between two or more dissimilar industries. ${ }^{7}$

The present work aims to evaluate the mechanical and physical properties of a new sustainable composite material that can arise from the implementation of an industrial symbiosis between steel and rubber industries. In Europe, the metallurgical industry annually produces about 60 million tons of electric arc furnace (EAF) steel, and Italy with an annual production of about 50 million tons is the leading produce. ${ }^{8}$ In this process, the main waste is the metallurgical slag with an estimated production of approximately $15 \mathrm{wt} \%$ of the produced steel.

The disposal of a vast amount of EAF slag represents a relevant cost for steel producers leading to severe environmental consequences. Many studies are available in the literature on the reuse of slag as an alternative aggregate to natural aggregates in asphalt ${ }^{9-11}$ and cement and concrete production, ${ }^{12-18}$ as fertilizer and soil improvement, ${ }^{19,20}$ 
and as filter or adsorbent in wastewater treatment plants. ${ }^{10,21,22}$ The reuse of EAF slag as aggregate for the construction industry leads to some criticisms such as concrete volumetric instability under extreme conditions and having higher water absorption than conventional road pavement materials. ${ }^{10}$ A 5-10 wt\% of EAF slag was found to produce Portland cement with compressive strength comparable to convectional cement; however, the main hurdle preventing EAF slag from being incorporated as a raw material for higher added value industrial applications is its inconsistent chemical composition, which can cause inconsistent properties. ${ }^{18,23}$ Regarding the reuse of EAF slag as fertilizer, if, on one hand, the presence of Fe, K, Mn, and $\mathrm{P}$ sustains plant growth, on the other, the presence of harmful elements makes some remediation procedures necessary to reduce them. ${ }^{10,24,25}$

Therefore, other recycling possibilities, among the traditional applications, become economically attractive for the steel industry, reducing the disposal costs and promoting the saving of natural resources. Cornacchia et al. ${ }^{26}$ proposed an alternative use of EAF slag as a reinforcing filler for polypropylene matrix, and recently the application of EAF slag as filler has been extended to other polymeric matrixes. ${ }^{27,28}$

Among the technical issues, another important aspect limiting the reuse of industrial waste is the regulatory one related to the classification of EAF slag as "waste" or "by-product." EAF slag can be classified as a "by-product" if it meets the requirements of Article 184 bis of Legislative Decree 152/ $2006,{ }^{29}$ which requires the $\mathrm{CE}$ marking. To obtain CE marking, the producer must therefore have a certified factory production control procedure. However, it often happens that despite slag having all the potential characteristics to be a by-product, the producer does not want to take on this management by assigning the status of "waste" to the EAF slag with the relative CER code. Recently, Italian legislation proposed the possibility to classify EAF slag as "end of waste," becoming a resource after a recovery process overcoming the regulatory issue. In this way, third-party companies are allowed to take charge of the treatment of the slag, which assumes the qualification of "end of waste" and after appropriate treatment get the CE marking for subsequent reuse.

After these premises, this work aims to assess an innovative application of EAF slag as a filler for vulcanized nitrile butadiene rubber (NBR) to prevent natural resource consumption and simultaneously contain environmental degradation, according to the circular economy.

NBR is an unsaturated thermosetting elastomer. The unsaturation in nitrile rubbers permits crosslinking by sulfur in conjunction with accelerators. Vulcanizing ingredients are generally incorporated, along with fillers such as carbon black and plasticizers to adjust flexibility, using open mills, internal mixers, extruders, and calenders. ${ }^{30}$ Finished products are usually produced by injection, compression, or transfer molding. NBR is one of the most widely commercialized and mass-produced elastomers for the automotive sector due to its high resistance to petrol and mineral oils.

For applications where the requirements are high hardness and stiffness, EAF slag could represent an alternative to high carbon black filled NBR. Since carbon black derives from hard coal tar, replacing it with a waste material results in a double environmental benefit, reducing both slag landfilling and carbon black production. Carbon black replacement has been studied in other studies; ${ }^{31-34}$ however, in the present work, it is partially replaced by a lowcost filler, e.g., the main waste material derived by the steel industry.

Furthermore, EAF slag could find application as a substitute for pure iron oxide whose use is studied as filler in rubber matrix to improve wear resistance, ${ }^{35}$ reduce the coefficient of friction, ${ }^{35}$ or give the final compound magnetic properties ${ }^{36}$. It should be emphasized that the addition of EAF slag in an elastomeric matrix gives the final compound magnetic properties that the elastomer alone does not possess. These properties can be exploited either in the application field or simply for the optimization of assembly.

The assessment of the economic and environmental impact of the reuse of slag in the context of industrial symbiosis was investigated for the traditional application in the civil engineering area showing relevant benefits. Dong et al. in their studies $^{37,38}$ reported that the reuse of blast furnaces (BFs) and basic oxygen furnaces (BOFs) in concrete production and road construction resulted in an avoided disposal cost of 5.19 million USD/year in Jinan, China. Similarly in Liuzhou, China, the reuse of $\mathrm{BF}$ and $\mathrm{BOF}$ slag led to a saving of approximately 2.4 million tons of raw materials and a reduction of approximately 3.4 million tons of solid waste. ${ }^{38-40}$

Regarding the environmental impact, Bonoli et al. ${ }^{41}$ investigated steel slag as an aggregate for asphalt concretes using the Life Cycle Assessment tool, and a positive impact on all eight factors envisaged by the LCA was highlighted.

This study aims to evaluate the technical characteristics of an NBR filled with EAF slag to define the possible applications. The technical critical points highlighted in traditional applications such as volumetric instability and leaching behavior in this new application as a filler for the polymeric matrix are reduced. In the elastomeric matrix, the volumetric variation is not relevant because of the elastic nature of the matrix, and the polymeric matrix, incorporating the slag particles, shields it from contact with water, also reducing its leaching behavior. $^{28}$ 
Once the possible applications have been defined, it will be possible to evaluate the environmental impact through a comparison between traditional material and innovative material at the same time as economic feasibility. Studies done on other applications have shown excellent results; however, similar studies will also have to be conducted for these new applications to quantify the benefits.

\section{MATERIALS AND METHODS}

\section{Materials}

EAF slag was supplied by the ASONEXT Spa (Ospitaletto BS, Italy) steelmaking plant. The slag was produced by a specific system named Slag-Rec ${ }^{42}$ for dry granulating EAF molten slag. EAF slag was ground and the pulverized EAF slag sieved to obtain a grain size $<106 \mu \mathrm{m}$. The vulcanized rubber used as a composite matrix was a nitrile butadiene rubber (NBR) with nominal hardness of 70 Shore A (carbon black $40 \mathrm{phr}$, vulcanized with sulfur) provided by Novotema Spa (Villongo BG, Italy). The influence of EAF slag as reinforcing filler for NBR was evaluated on four different compounds with different amounts of filler and the results compared to that of standard NBR.

The tested compounds are:

- Standard NBR as a reference, which is only compression-molded;

- NBR $0 \%$, which is a standard NBR calendered and compression-molded;

- Four compounds filled with EAF slag at 5, 10, 20, and $30 \% \mathrm{v} / \mathrm{v}$ calendered and compression-molded.

The compounding process was performed to disperse the filler particles in the NBR matrix by calendering process. The calendering process consists of forcing rubber and slag between two rotating cylinders (diameter of $150 \mathrm{~mm}$ ) $0.1 \mathrm{~mm}$ apart at room temperature. The calender machine was provided by Meccaniche Moderne srl (Busto Arsizio VA, Italy). In the calendering process, the uncured rubber is worked in several steps during which the temperature increases $\left(70-80{ }^{\circ} \mathrm{C}\right)$ because of the high shear stresses generated by the cylinder in the material that gets soft. The compounds are then compression molded for $15 \mathrm{~min}$ at $180{ }^{\circ} \mathrm{C}$ at $40 \mathrm{MPa}$ to obtain test plates with dimensions of $200 \times 200 \times$ $2 \mathrm{~mm}$ and $100 \times 60 \times 6 \mathrm{~mm}$ from which samples for mechanical tests are obtained by mechanical punching.

\section{Methods}

\section{EAF Slag Characterization}

EAF slag chemical composition is determined by x-ray fluorescence spectroscopy carried out by the Thermo Scientific ${ }^{\mathrm{TM}}$ ARL ${ }^{\mathrm{TM}}$ PERFORM'X provided by Thermo Fisher Scientific TM (Waltham, MA,
Table I. EAF slag chemical composition determined by x-ray fluorescence spectroscopy.

\begin{tabular}{lcr}
\hline $\mathrm{SiO}_{2}$ & 9.45 & {$[\% \mathrm{wt}]$} \\
$\mathrm{Al}_{2} \mathrm{O}_{3}$ & 7.61 & {$[\% \mathrm{wt}]$} \\
$\mathrm{Fe}_{2} \mathrm{O}_{3}$ & 40.19 & {$[\% \mathrm{wt}]$} \\
$\mathrm{MnO}$ & 5.58 & {$[\% \mathrm{wt}]$} \\
$\mathrm{CaO}$ & 29.8 & {$[\% \mathrm{wt}]$} \\
$\mathrm{MgO}$ & 3.64 & {$[\% \mathrm{wt}]$} \\
$\mathrm{P}_{2} \mathrm{O}_{5}$ & 0.48 & {$[\% \mathrm{wt}]$} \\
$\mathrm{TiO}_{2}$ & 0.38 & {$[\% \mathrm{wt}]$} \\
$\mathrm{Cr}_{2} \mathrm{O}_{3}$ & 2.30 & {$[\% \mathrm{wt}]$} \\
$\mathrm{S}$ & 0.09 & {$[\% \mathrm{wt}]$} \\
$\mathrm{Na}_{2} \mathrm{O}$ & 0.44 & {$[\% \mathrm{wt}]$} \\
$\mathrm{K}_{2} \mathrm{O}$ & 0.01 & {$[\% \mathrm{wt}]$} \\
$\mathrm{F}$ & 0.00 & {$[\% \mathrm{wt}]$} \\
$\mathrm{Sum}$ & 100.00 & {$[\% \mathrm{wt}]$} \\
$\mathrm{Basicity}_{\mathrm{CaO} / \mathrm{Al}} \mathrm{O}_{3}$ & 0.62 & {$[\% \mathrm{wt}]$} \\
$\mathrm{Al}{ }_{2} \mathrm{O}_{3} / \mathrm{SiO}$ & $3 \% \mathrm{wt}]$ \\
$\mathrm{IB} 2: \mathrm{CaO} / \mathrm{SiO}$ & {$[\% \mathrm{wt}]$} \\
$\mathrm{IB} 4: \mathrm{CaO}+\mathrm{MgO}) /\left(\mathrm{SiO}_{2}+\mathrm{Al}_{2} \mathrm{O}_{3}\right)$ & 3.92 & {$[\% \mathrm{wt}]$} \\
\hline
\end{tabular}

USA). EAF slag's chemical composition is reported in Table I.

Slag is a heterogeneous material consisting of different phases. To reduce this heterogeneity, the slag used in this study was produced by a specific system named Slag-Rec. ${ }^{42}$ The Slag-Rec system is a process designed to manage the slag as a co-product: after slugging, the slag is rapidly cooled as it passes between two water-cooled cylinders to form a thin plate that is easy to crush. Rapid cooling allows the formation of a fine microstructure consisting of phases characterized by low leaching of heavy elements. ${ }^{43}$

The identification of the phases and structure of the slag was performed by SEM-EDXS (SEM Leo Evo 40, Carl Zeiss, Oberkochen, Germany; EDXS microprobe Link Pentafet Oxford model 7060; Oxford Instruments, Oxfordshire, UK); a standard metallographic polishing procedure was used. The identified phases and related chemical composition are shown in Fig. 1.

The leaching of heavy metals was determined according to the standard CEN-EN 12457-2. ${ }^{44}$ For this analysis, the slag was ground by a mortar and successively sieved to obtain a grain size $<4 \mathrm{~mm}$.

The leachates were analyzed by a Perkin Elmer Avio 200 ICP Optical Emission Spectrometer (Milan, Italy) to measure the concentration in the $\mathrm{Cr}, \mathrm{Mo}$, and V solution (Table II). The results of the leaching test carried out according to the standard CEN EN $12457-2^{44}$ are given in Table II.

Although the standard requires a grain size $<4$ $\mathrm{mm}$, in order to evaluate the influence of the grain size on the leaching behavior, the test was also performed on slag grain size sieved between 4 and 3 $\mathrm{mm}$, between 1 and $2 \mathrm{~mm}$ and $<0.106 \mathrm{~mm}$. Tests were performed twice, and the highest detected concentration of Mo, Cr, and V is shown in Fig. 2. 


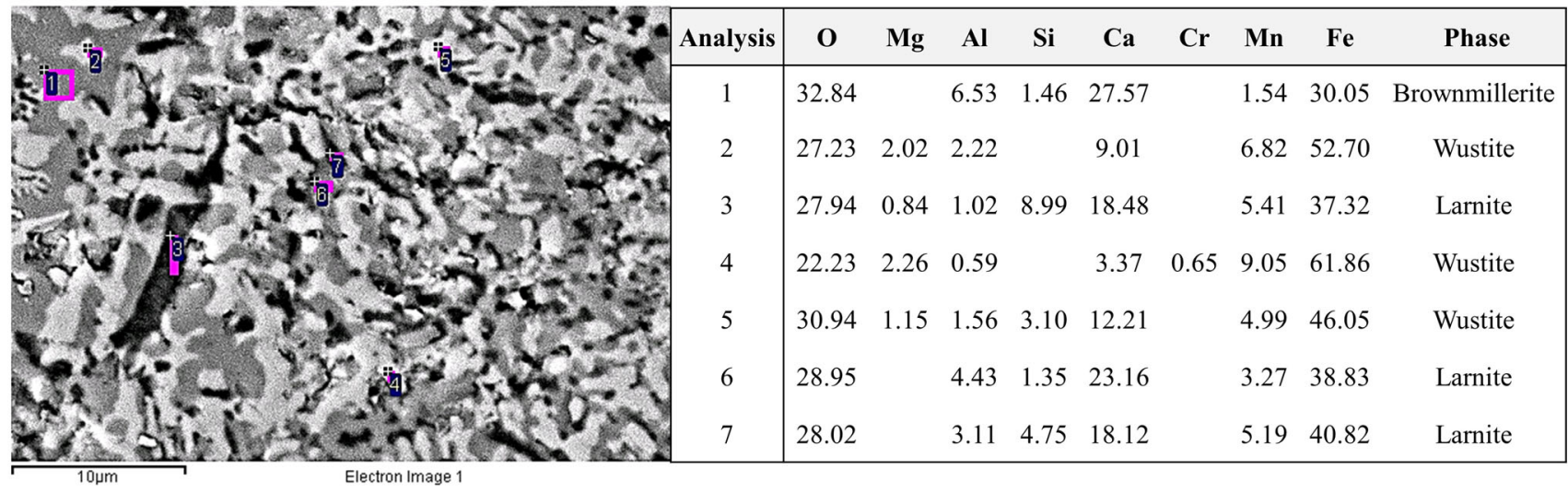

Fig. 1. SEM back-scattered electron (BSE) image of slag microstructure with its EDXS analysis on metallographic polishing. Analysis are reported in [\%wt]

Table II. Leaching test CEN EN 12457-2 results for EAF slag (grain size $<4$ mm) and NBR filled with EAF slag at $30 \% \mathrm{v} / \mathrm{v}$ (grain size $<106$ microns). Mo, Cr, and V concentration determined by ICP Optical Emission Spectrometer

\begin{tabular}{lccc}
\hline & & Free EAF slag (grain size $<$ 4 mm) & NBR 30\% [\%v/v] EAF slag \\
\cline { 2 - 3 } Electrical conductivity & $\mu \mathrm{s}$ & $816 \pm 231$ & $253 \pm 18$ \\
$\mathrm{nH}$ & {$[-]$} & $11.84 \pm 0.18$ & $11.4 \pm 0.01$ \\
$\mathrm{Mo}$ & $\mathrm{mg} / \mathrm{L}$ & $0.15 \pm 0.07$ & $0.019 \pm 0.002$ \\
$\mathrm{Cr}$ & $\mathrm{mg} / \mathrm{L}$ & $0.073 \pm 0.005$ & $0.002 \pm 0.001$ \\
$\mathrm{~V}$ & $\mathrm{mg} / \mathrm{L}$ & $0.15 \pm 0.11$ & $0.17 \pm 0.01$ \\
\hline
\end{tabular}

The weights of slag and rubber to be compounded to obtain the desired percentage by volume of filler are determined by a preliminary density test of rubber and slag. The density measurements were carried out according to standard ASTM D792. ${ }^{45}$

\section{Compound Characterization}

The correctness of the slag and rubber amount in the different compounds was verified retrospectively by density measurements and thermogravimetric analysis (TGA) (see Table III), which were carried out on specimens weighing between 7 and $15 \mathrm{mg}$ and heating rate of $10{ }^{\circ} \mathrm{C} / \mathrm{min}$. The samples were heated from room temperature up to $700{ }^{\circ} \mathrm{C}$ to determine the complete thermal degradation of the NBR matrix. The TGA curves were obtained in air. The residue measured by the TGA is slightly higher than the nominal one because in the standard NBR there are other fillers in addition to EAF slags such as accelerators, activators, antioxidants, and antiaging. Nevertheless, by subtracting the standard NBR residue, the percentage by weight of EAF slag in the various compounds is lower than the nominal one. This is probably due to the loss of a certain amount of slag dust during the calendering process. Even the density measured on the different compounds is slightly lower than the theoretical one, as shown in Table III.
The influence of EAF slag on the processability characteristic is assessed by the parameters extrapolated by the rheometric curves, determined by the rheometer machine provided by Gibitre Instruments (Bergamo, Italy). The temperature of the rheometer plates is $177^{\circ} \mathrm{C}$, and an oscillating force is applied to the sample with an oscillating amplitude of $0.5^{\circ}$. Testing time is about $3 \mathrm{~min}$. One sample for each compound is tested. The rheometric curves were defined according to the standard ASTM D5289. ${ }^{46}$

The compounds' hardness was measured according to the most widely used scales in the rubber industry: Shore A hardness and micro International Rubber Hardness Grade (mIRHD). The Shore A measurements were carried out by a Shore PC type A automatic hardness tester provided by Gibitre Instruments (Bergamo, Italy). The mIRHD measurements were carried out by a Micro IRHD-PC automatic hardness tester provided by Gibitre Instruments (Bergamo, Italy). Shore A measurements were carried out according to the standard ISO7619-1, ${ }^{47}$ The mIRHD measurements were carried out according to the standard ISO $48 .^{48}$

Compression tests were performed on three samples for each material by a dynamometer (mod. 3366) provided by Instron (Pianezza, TO, Italy) at room temperature and a strain rate of $10 \mathrm{~mm} / \mathrm{min}$. Cylindrical specimens with a nominal diameter of 


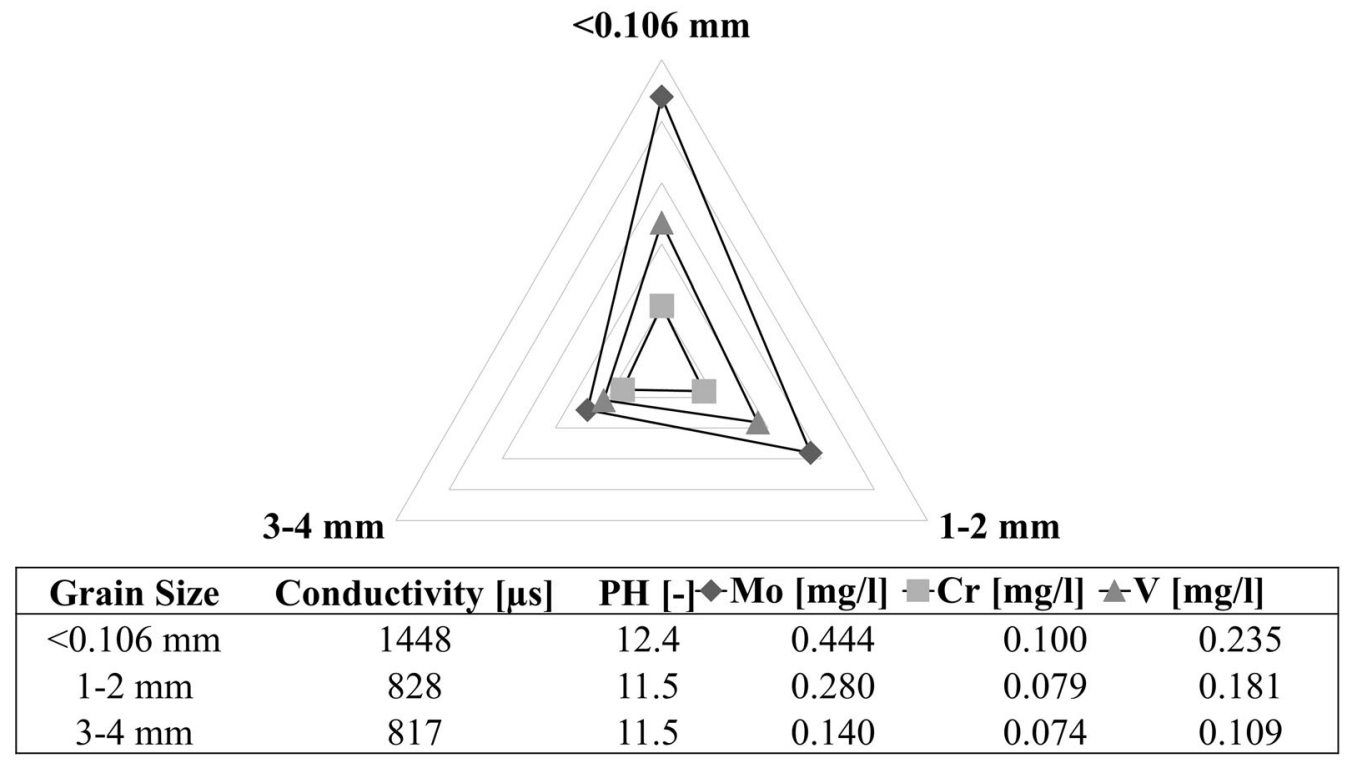

Fig. 2. Leaching test results for different EAF slag grain sizes: $<0.106 \mathrm{~mm}$, between 1 and $2 \mathrm{~mm}$, and between 3 and $4 \mathrm{~mm}$.

Table III. Nominal percentage of EAF slag as filler and real percentage of all fillers measured by TGA. Nominal and measured densities of compounds filled with different amounts of EAF slag

\begin{tabular}{|c|c|c|c|c|}
\hline \multicolumn{2}{|c|}{ EAF slag } & \multirow{2}{*}{$\frac{\text { Residue measured by TGA }}{[\mathrm{wt} \%]}$} & \multirow{2}{*}{$\frac{\text { Nominal density }}{\left[\mathrm{g} / \mathrm{cm}^{3}\right]}$} & \multirow{2}{*}{$\frac{\text { Measured density }}{\left[\mathrm{g} / \mathrm{cm}^{3}\right]}$} \\
\hline$[\% \mathbf{v} / \mathbf{v}]$ & [wt $\%]$ & & & \\
\hline 0 & 0 & 3.40 & 1.240 & $1.240 \pm 0.010$ \\
\hline 5 & 14 & 16.46 & 1.366 & $1.349 \pm 0.001$ \\
\hline 10 & 26 & 26.59 & 1.496 & $1.469 \pm 0.009$ \\
\hline 20 & 44 & 46.68 & 1.752 & $1.722 \pm 0.001$ \\
\hline 30 & 57 & 59.77 & 2.013 & $2.005 \pm 0.004$ \\
\hline
\end{tabular}

$12 \mathrm{~mm}$ and a height of $6 \mathrm{~mm}$ were produced for this test. A picture of the compression test performed on EAF slag-filled NBR $30 \% \mathrm{v} / \mathrm{v}$ as an example is reported in Fig. 3a. The compression test was performed according to the standard ISO $7743 .{ }^{49}$ The compression set was determined by imposing a compression deformation of $25 \%$ on cylindrical samples (nominal diameter $12 \mathrm{~mm}$ and height of 6 $\mathrm{mm}$ ) for $24 \mathrm{~h}$ at $100{ }^{\circ} \mathrm{C}$. The compression set fixture is shown in Fig. 3b. The compression set was determined according to standard ASTM D395 (test method B). ${ }^{50}$

The presence of iron/iron oxides in the slag gives the composite magnetic properties. The magnetic attraction force was evaluated by quantifying the force required to detach a magnet from the NBR filled with different amounts of EAF slag. A magnet was fixed to the beam of the dynamometer in contact with the material, moving the beam at a speed of $10 \mathrm{~mm} / \mathrm{min}$, and a $500 \mathrm{~N}$ load cell detected the load every $0.01 \mathrm{~s}$. The peak of the curve obtained is identified as the detachment load.
The leaching test on the composite material with the highest filler content (i.e., 30\%v/v) was conducted as for the free slag, following the CEN-EN 12457-2 standard. ${ }^{44}$ The results are reported in Table II. The composite material plate was cut to a particle size $<4 \mathrm{~mm}$, and the slag dust lost from the cutting surface was removed to evaluate only the inertizing effect of the polymer matrix. As for the characterization of free slag, the amount of tested composite was calculated to maintain the $90 \mathrm{~g}$ of slag in a ratio of 1:10 with the liquid, according to the standard. ${ }^{44}$

\section{RESULTS AND DISCUSSION}

\section{EAF Slag}

The chemical composition of the slag is strongly influenced by the production process and the raw materials used during the smelting process. Concerning the mineralogy of the slag, its composition is very similar to that of effusive rocks; the microstructure is strongly influenced by both the chemical composition of the slag in the molten state and the 

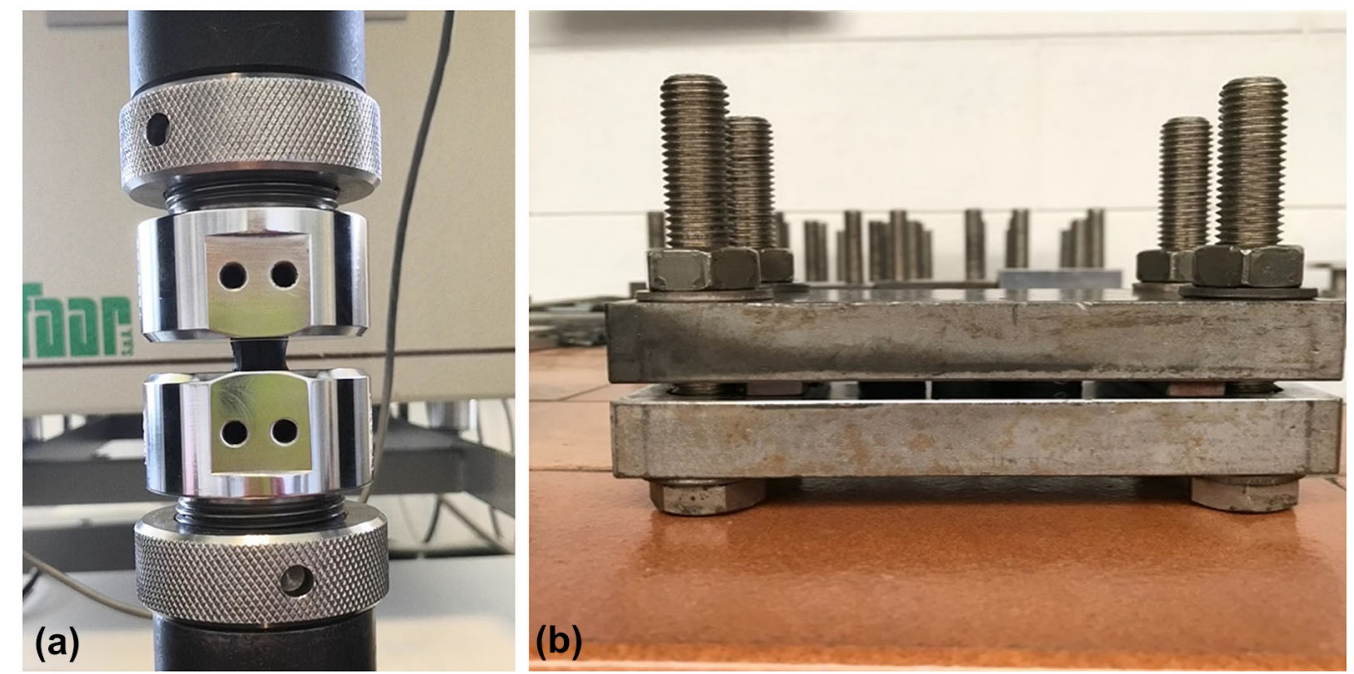

Fig. 3. (a) Compression test performed by Instron dynamometer (model 336 ) at $10 \mathrm{~mm} / \mathrm{min}$ on EAF slag filled NBR $30 \% \mathrm{v} / \mathrm{v}$. (b) Compression set fixture set at compression strain $25 \%$.

cooling rate. ${ }^{43,51,52}$ The literature reports the effects of slagging procedures on the mineralogical and morphological structure of EAF slags. ${ }^{43,53}$ The crystalline phases usually identified are larnite $\left(2 \mathrm{CaOSiO}_{2}\right)$, brownmillerite $\left(\mathrm{Ca}_{2}(\mathrm{Al}, \mathrm{Fe}) 2 \mathrm{O}_{5}\right)$, wustite $(\mathrm{FeO})$, calcium silicate, silicon aluminates, gehlenite $\left(\mathrm{Ca}_{2} \mathrm{Al}\left(\mathrm{AlSiO}_{7}\right)\right)$, bredigite $\left(\mathrm{Ca}_{7} \mathrm{Mg}\left(\mathrm{SiO}_{4}\right)\right.$ 4 ), magnetite $\left(\mathrm{Fe}_{3} \mathrm{O}_{4}\right)$, magnesioferrite $\left(\mathrm{MgFe}_{2} \mathrm{O}_{4}\right)$, and manganese oxides. ${ }^{54}$

The chemical composition of the EAF slag used as filler in this work is given in Table I. The main components of slags are iron oxide $\left(\mathrm{Fe}_{2} \mathrm{O}_{3}\right)$ and calcium oxide $(\mathrm{CaO})$, and the basicity index IB2 $=\mathrm{CaO} / \mathrm{SiO}_{2}$ is equal to 3.15. It is important to note that if the basicity factor calculated as IB4 $(\mathrm{CaO}+\mathrm{MgO}) /\left(\mathrm{SiO}_{2}\right.$ $+\mathrm{Al}_{2} \mathrm{O}_{3}$ ) is $>1$ (as in this case), the glass can form. The glass phase shelves the heavy metals and prevent them from leaching. ${ }^{43}$

SEM-EDXS analysis identified three main phases: iron oxide, principally wustite $(\mathrm{FeO})$, containing a small quantity of $\mathrm{Ca}$ and $\mathrm{Mn}$, and brownmillerite $\left(\mathrm{Ca}_{2}(\mathrm{Al}, \mathrm{Fe})_{2} \mathrm{O}_{5}\right)$ and larnite $\left(\mathrm{Ca}_{2} \mathrm{SiO}_{4}\right)$. The high $\mathrm{Fe}$ content found in larnite is attributable to the reading of surrounding phases, which, due to the very fine microstructure, are difficult to exclude.

The safe use of slag requires that its characteristics comply with specified limits to guarantee chemical inertia. This means not only that slag's chemical composition must fall within specified ranges, but also that the release of heavy metals into the environment must be kept under strict control. The possible release of heavy metals must be checked by the leaching test according to the standard CEN-EN 12457-2. ${ }^{44}$ Differences in the results are expected due to the variability of the slags, which can also be elevated in the same steel casting. ${ }^{55}$
Table II shows the results of the leaching of heavy metals such as $\mathrm{Cr}$, Mo, and $\mathrm{V}$ for the slag and composite NBR filled with 30\% EAF, determined according to the standard CEN-EN $12457-2 .{ }^{44}$ Comparing the slag and composite shows that the leaching of Mo, Cr, and V has been reduced in the new material; in particular, $\mathrm{Cr}$ and $\mathrm{Mo}$ have decreased by more than one order of magnitude. It should be emphasized that the inertizing effect of the polymeric matrix must be considered in a context where the slag incorporated in the rubber is not the same tested as free slag although it comes from the same casting. Confirming these results, the inertizing effect of the polymer matrix has already been noted in another study ${ }^{26}$ where it is more evident, probably because of the particle size used in the polypropylene composite $(<106 \mu \mathrm{m})$. Extensive literature has demonstrated that the release of the heavy metal increases with decreasing granulometry of the slag ${ }^{55-58}$, and this trend was also confirmed in this study as shown in Fig. 2. The effect of the particle size is particularly marked for Mo, although a slight reduction is also observed for $\mathrm{Cr}$ and $\mathrm{V}$ leaching. Notably, the $\mathrm{pH}$ value of EAF slag in a grain size $<0.106 \mathrm{~mm}$ is $>12$, which is caustic and corrosive. Also, electrical conductivity of the finest grain size range is markedly higher and is considerably reduced with the incorporation of the slag in the rubber because of its reduced heavy metal leaching. ${ }^{59}$

The mechanism at the basis of the reduction of heavy metals leaching is based on NBR's characteristic of being a hydrophobic material. In accordance with, ${ }^{60}$ the absorption of water by the NBR matrix is very low; therefore, the contact between the slag particles and water is limited only to the particles not completely incorporated (at the edges of the surfaces). Therefore, it is possible to state that 
Table IV. Rheometric curve data for standard NBR and NBR filled with EAF slag at 0, 5, 10, 20, and 30\%v/v

\begin{tabular}{|c|c|c|c|c|c|c|c|}
\hline \multirow[b]{3}{*}{ Compound } & \multicolumn{5}{|c|}{ Phase 1} & \multirow{3}{*}{$\frac{\frac{\text { Phase 2 }}{\text { t90 }}}{[s]}$} & \multirow{3}{*}{$\frac{\text { Phase 3 }}{\text { MaxT }} \frac{\text { [dN*m] }}{\mathbf{d N}^{*} \mathbf{m}}$} \\
\hline & $\mathbf{I T}$ & MinT & $\underline{\text { Ts1 }}$ & $\underline{\text { Ts2 }}$ & $\underline{\mathbf{t 5 0}}$ & & \\
\hline & {$\left[\mathbf{d N} \mathbf{N}^{*} \mathbf{m}\right.$} & {$\left[d N^{*} m\right]$} & [s] & [s] & {$[\mathbf{s}]$} & & \\
\hline Standard NBR & 3 & 1.06 & 46 & 54 & 81 & 123 & 18.04 \\
\hline 0 [\%v/v] EAF slag & 1.84 & 0.84 & 45 & 52 & 78 & 121 & 16.91 \\
\hline $5 \%[\% \mathrm{v} / \mathrm{v}]$ EAF slag & 2.76 & 0.89 & 45 & 52 & 79 & 125 & 18.44 \\
\hline $10 \%[\% \mathrm{v} / \mathrm{v}]$ EAF slag & 3.1 & 0.95 & 43 & 51 & 78 & 122 & 20.28 \\
\hline $20 \%[\% \mathrm{v} / \mathrm{v}] \mathrm{EAF}$ slag & 4.1 & 1.16 & 43 & 50 & 79 & 120 & 24.47 \\
\hline $30 \%[\% \mathrm{v} / \mathrm{v}]$ EAF slag & 5.93 & 1.54 & 37 & 44 & 75 & 113 & 31.48 \\
\hline
\end{tabular}

as the volume/surface ratio of a generic component increases, leaching will be reduced.

Finally, it should be noted that according to Italian legislation and concerning the leaching of $\mathrm{Mo}, \mathrm{Cr}$, and $\mathrm{V}$, the free slag tested in accordance with CEN EN 12457-2 ${ }^{44}$ (grain size $<4 \mathrm{~mm}$ ) is appropriate for being disposed of as non-hazardous waste $(\mathrm{Cr}, \mathrm{Mo}<1 \mathrm{mg} / \mathrm{L}){ }^{61}$ while the slag incorporated in rubber matrix is compliant with the requirements for the recovery of material $(\mathrm{Cr}<$ 0.05 and $\mathrm{V}<0.25 \mathrm{mg} / \mathrm{L})^{62}$ and can be disposed of in landfills as inert waste $\mathrm{Cr}, \mathrm{Mo}<0.05 \mathrm{mg} / \mathrm{L} .{ }^{61}$

\section{NBR/slag composite}

The rheometric curve data are given in Table IV. The rheometric curve provides indications regarding the processability characteristics (phase 1), curing kinetics (phase 2), and physical properties (phase 3) of the tested materials. In phase 1, note that as a general trend initial torque (IT) and minimum torque (MinT) increase with increasing of the filler amount in the compound. The IT behavior allows to observe that the high-filled compound just placed in the chamber offers more resistance to torque than the low-filled one. MinT is the parameter related to the material viscosity; in this case, its trend indicates that by increasing the amount of slag in NBR the viscosity slightly increases. This phenomenon is probably due to the presence of rigid filler, which limits the mobility of the polymer chains even before the starting point of the vulcanization process. The time during which this first phase occurs is called the scorch time, specifically the time at which the curing starts. It is related to the parameters Ts1 and Ts2 (the time at which the minimum moment increases by $1 \mathrm{dN} * \mathrm{~m}$ and $2 \mathrm{dN} * \mathrm{~m}$, respectively). The scorch time is shortened by increasing the amount of filler, and this means that the material can stay in the injection chamber without vulcanizing for a shorter time.

In phase 2, t50 and t90 (time at which $50 \%$ and $90 \%$ of the vulcanization are reached) get shorter by increasing the amount of filler. The presence of slag as filler accelerates crosslinking kinetics because of two different mechanisms. In the first mechanism, the reduction of scorch and curing time is associated with the increase of the compound viscosity and shear heating effect. The second mechanism is related to the NBR volume fraction, which is reduced by increasing the amount of filler so that the crosslinking reaches $100 \%$ faster. From the injection molding production process point of view, this is a great advantage because it allows reducing the production cycle time, saving on production costs.

In phase 3 , the maximum torque (MaxT) is determined. By increasing the amount of filler in the compound, the torque needed to maintain the imposed rotation at complete vulcanization increases. This means the high-filled compound gets harder.

The influence of the calendering process on standard NBR slightly accelerates the vulcanization kinetics and softens the material. On the other hand, the presence of EAF slag as filler in the rubber matrix hardens the compound and accelerates the vulcanization kinetics. The same trend was found in the literature for several fillers: silica and multiwall carbon nanotubes as found by Salehi et al. ${ }^{63}$, iron oxide obtained by El-Tantawy et al. ${ }^{36}$, and nano-calcium carbonate as observed by Kumarjyoti et al. ${ }^{64}$.

Figure 4 shows the hardness results obtained for NBR compounds filled with different amounts of EAF slag in mIRHD and Shore A measurement scales. Numerical values are reported in Supplementary Table S1. It is possible to notice that with increasing the amount of EAF slag, the hardness in both measurement scales increases from a value of about 63 up to a value of 75 . According to Wang et al. $^{35}$, the reason for this increase is the hardness of the EAF slag, which is bigger with respect to the NBR one. This property of slag allowed an increase of the hardness of the composites proportionally to the quantity added. Regarding the influence of the calendering process, it does not affect the hardness of standard NBR (see Supplementary Table S1).

Compression test was performed, and compression Young's modulus value and the stress at 50\% compression strain acquired from the stress strain 


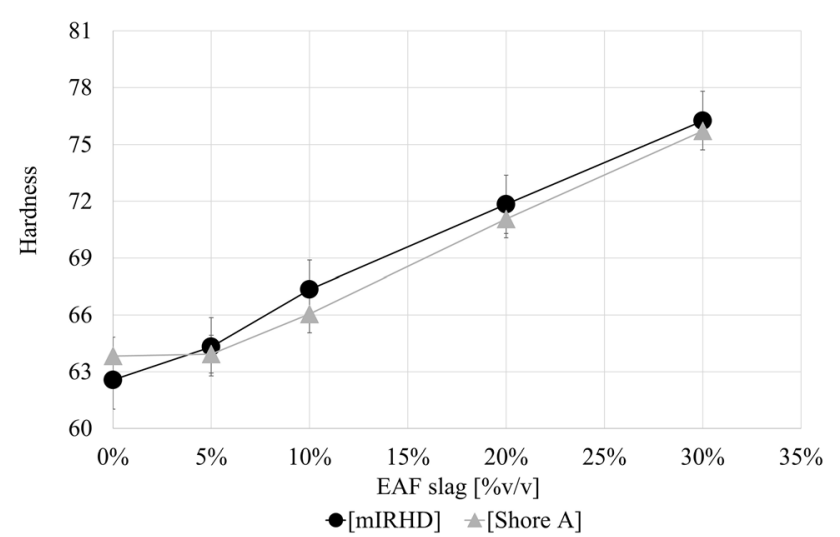

Fig. 4. Hardness results in Shore A and IRHD for NBR compounds filled with EAF slag.

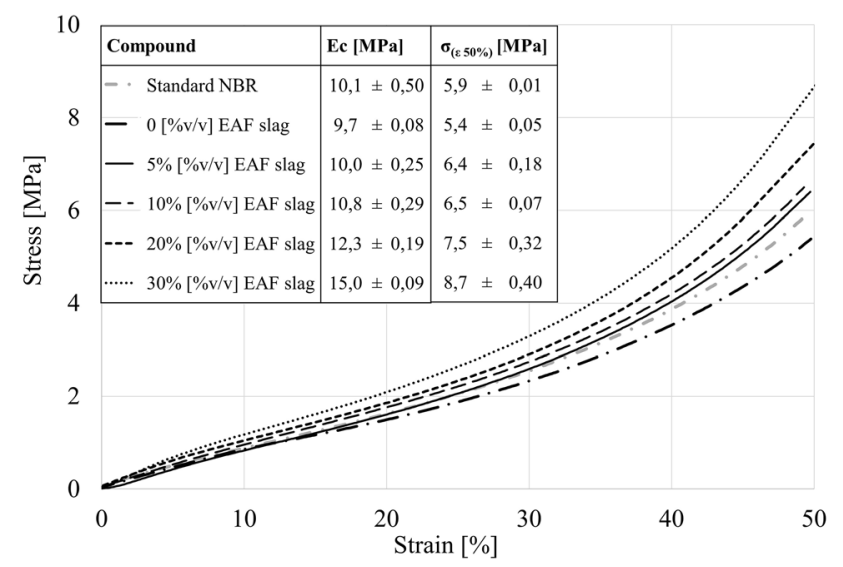

Fig. 5. Compression stress-strain curve of Standard NBR and EAF slag filled NBR at $0,5,10,20$, and $30 \% \mathrm{v} / \mathrm{v}$.

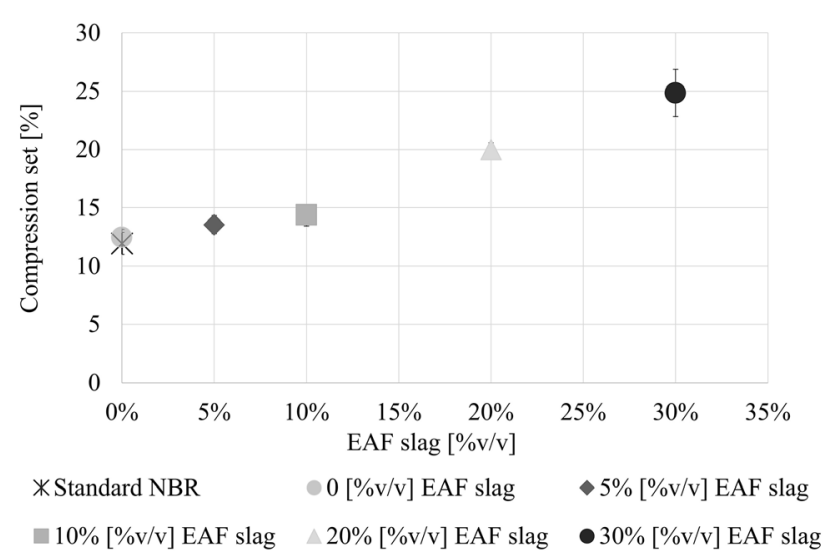

Fig. 6. Compression set function of the percentage of EAF slag in NBR matrix.

curves are reported in Fig. 5 . The compression test results show that the material offers a greater deformation resistance with increasing slag content. The calendering process in the compression test results allows to observe a softening of the calendered compound compared to the standard NBR in Fig. 5. It is possible to observe how the compression Young's modulus increases remarkably with the increments of slag filler up to an increase of $50 \%$ for NBR with slag at $30 \% \mathrm{v} / \mathrm{v}$ with respect to standard NBR (Fig. 5).

The compression set results are reported in Fig. 6. Numerical values are reported in Supplementary Table S2. In this case, the presence of EAF slag as filler reduces the material's ability to recover an imposed deformation proportionally to the amount of filler added. Note that up to a filler content of $10 \% \mathrm{v} / \mathrm{v}$ the compression set is $>15 \%$, which is a good value for real applications. Nevertheless, a compression set value of $20 \%$ is still acceptable for real applications.

Analyzing the results of the compression test and compression set, the increase of stiffness could be a positive aspect for new compounds. In a real application, rubber gaskets could be assembled in displacement control or load control as shown in Fig. $7 \mathrm{~b}$ and c, respectively. Notably, the correct assembly of a gasket in a sealing system does not provide their presence in the center of the slot, but rather leans it against the wall of the housing on the opposite side to the direction of the operating pressure, as shown in Fig. 7a.

In both configurations (Fig. $7 \mathrm{~b}$ and c), the O-rings fit in the groove, and the housing, with overlap, provides initial preload after assembly (Fig. 7a). This preload $(\mathrm{Pc})$ with operating pressure (Pf) allows to obtain the sealing effect. When the O-ring is pressed to the side of the groove, it deforms and the pressure is transferred to the surrounding surfaces (Fig. 7b and c). The operating pressure (Pf) is superimposed on the initial pressure because the pressure propagates the material without weakening as the vulcanized rubber is nearly incompressible. Despite this, as the material shows viscoelastic behavior and relaxes, the maximal contact pressure will be slightly less (about 80\%) than the sum of the two pressures. ${ }^{65}$ According to Szabò et al. ${ }^{65}$, the overall contact area increases as the O-ring deforms and the maximum value of the contact pressure is at the side of the O-ring where it touches the shaft.

If a gasket is assembled in a displacement-controlled sealing system as shown in Fig. 7b, the high filled rubber (gray) requires higher clamping force due to its higher stiffness, and this results in higher contact pressure compared to standard NBR (black) $(\mathrm{Pc} 2>\mathrm{Pc} 1)$. This is a great advantage since the necessary condition for a sealing system to function properly is that the contact pressure is greater than the fluid pressure $(\mathrm{Pc}+\simeq 0.8 \mathrm{Pf}>\mathrm{Pf})$.

Regarding the contact pressure trend over time, the NBR filled with EAF slag has a higher compression set so, according to the relationship between compression set and compression stress relaxation, it drops faster with respect to standard 
(a)

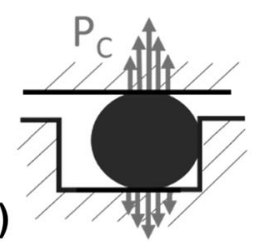

(b) $\varepsilon \%=\operatorname{cost}$

(c) $P_{c}=$ cost
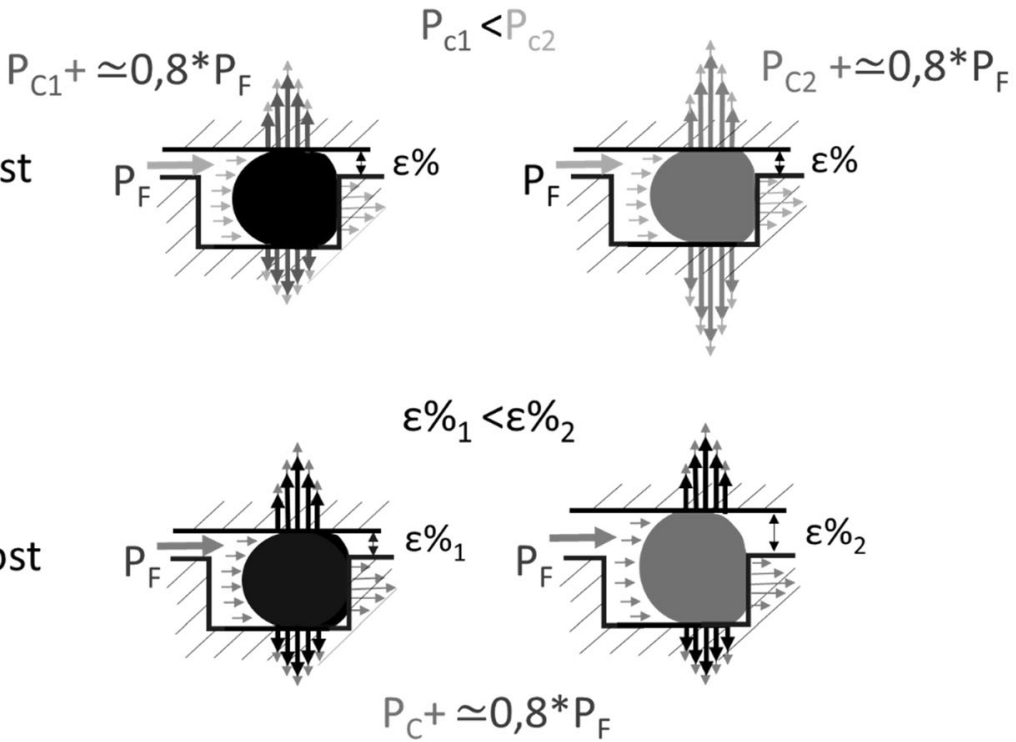

Fig. 7. Schematic of a sealing system without operating pressure (Pf) (a) and with operating pressure (Pf) assembled in displacement control (b) and load control (c) for NBR standard (black) and a standard NBR filled with EAF slag (gray).

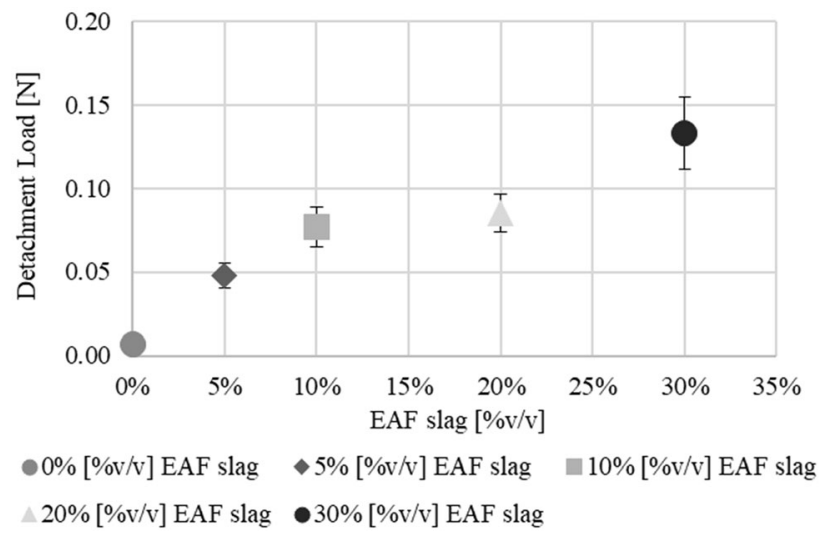

Fig. 8. Detachment force between a magnet and the compound filled with EAF slag in different quantities.

NBR. In the literature, the direct relationship between the compression stress relaxation and compression set is observed $;^{66,67}$ in particular, an increase of the compression set corresponds to a decrease of the contact pressure due to the compression stress relaxation. On the one hand, the initial contact pressure of the NBR filled with EAF slag, known from the compression test, is higher than that of the standard NBR (in proportion to the amount of filler added); on the other hand, the compression set of the NBR filled with EAF slag is slightly higher than that of the standard NBR. From these results, it is possible to assume that the filled NBR contact pressure at a sufficiently long time for the stress relaxation to settle at a constant value is in any case greater than that of standard NBR.

If a gasket is assembled in a load-controlled sealing system (Fig. 7c) with equal contact pressure, the high-filled NBR is less deformed than the standard NBR. As a result of the different initial deformation, the filled NBR contact pressure falls less steeply over time compared to standard NBR because of its lower initial deformation. ${ }^{68}$ It is important to highlight that, in both sealing system configurations, the EAF slag as filler positively affects the compound properties.

Figure 8 shows the force required to detach a magnet from the NBR filled with different amounts of EAF slag. Numerical values are reported in Supplementary Table S3. As expected, the standard NBR does not require any detachment load but, by adding an increasing amount of EAF slag as filler, the detachment load grows. This force is still low compared to a metallic material but may be sufficient for mounting applications where the magnetic force helps the rubber part to seat. For example, in automatic assembly systems, to handle a rubber part it will be sufficient to apply a magnet to the end of the robotic arm. This solution, in addition to being economical in terms of equipment required, also minimizes the risk of damage to the rubber compared to a mechanical handling system by clamps that could generate micro cracks causing malfunctions in operation. From an application point of view, EAF slag gives NBR ferromagnetic properties so it can potentially be used as a shield for magnetic fields. Ferromagnetic materials, having a higher permeability than air, offer a preferential path to the magnetic field. In this way they absorb the flux lines of the magnetic field from the area around the source to be shielded. Obviously for this application a specific characterization of the material will be required, which is not the purpose of this study. 


\section{CONCLUSION}

The aim of this work is the characterization of an innovative compound consisting of vulcanized rubber NBR filled with EAF slag, in order to pave the way to a new EAF slag application that is economically and environmentally sound. The influence of four different amounts of EAF slag $(5,10,20$, and $30 \% \mathrm{v} / \mathrm{v})$ was evaluated compared with standard NBR. The main results can be summarized as follow:

- Still today a large amount of EAF slag is disposed of as special waste. For safe reuse of slag, the leaching of heavy metals must remain under specific values. The leaching of $\mathrm{Cr}, \mathrm{Mo}$, and $\mathrm{V}$ of EAF slag incorporated in the rubber matrix is significantly reduced compared to that of free slag.

- The processability characteristics of the analyzed compound were evaluated by the rheometric curve. The results show that a higher amount of slag in NBR slightly increases the compound viscosity and accelerates the crosslinking kinetics. From the production point of view, this is a great advantage because it allows reducing the production cycle time, saving on production costs. On the other hand, this phenomenon reduces the scorch time, so that the time during which the material can stay in the injection chamber without vulcanizing is less. The risk of producing non-compliant rubber parts is higher. Finally, the rheometric curve data show an increase in the torque needed to maintain the imposed rotation at complete vulcanization.

- Compression modulus increases with growing of the filler amount by 50\% from standard NBR to NBR filled with EAF slag at $30 \% \mathrm{v} / \mathrm{v}$. The compression test results demonstrate that by increasing the amount of slag, the material offers an everincreasing resistance to deformation.

- Hardness value (both Shore A and mIRHD) increases with increasing amount of added filler.

- Compression set results show that the presence of filler reduces the material's ability to recover an imposed deformation; up to a filler content of $10 \% \mathrm{v} / \mathrm{v}$ the compression set is $>15 \%$, which is a good value for real applications, while for a filler content of $20 \% \mathrm{v} / \mathrm{v}$ it is $<20 \%$, which is still acceptable.

- In the real case of a gasket assembled in load control or displacement control, comparing the performance of a standard NBR and an NBR filled with EAF slag it is possible to observe that in both assembly configurations EAF slag affects the compound properties positively.

- The addition of metal slag in an elastomeric matrix gives the final compound magnetic properties that the elastomer alone does not possess. These properties can be exploited both in the application field or simply for the optimization of assembly. The force required to detach a magnet from the compound increases as the added EAF slag amount increases.

\section{ACKNOWLEDGMENTS}

Authors thank Asonext Spa (Ospitaletto(BS), Italy) and Novotema S.p.A - Idex Corporation (Villongo (BG), Italy) for providing materials and test equipment for the characterization of EAF slag and rubber composites and acknowledge Lombardy Region and ENEA for the PhD scholarship of AG.

\section{CONFLICT OF INTEREST}

The authors declare that they have no conflict of interest.

\section{OPEN ACCESS}

This article is licensed under a Creative Commons Attribution 4.0 International License, which permits use, sharing, adaptation, distribution and reproduction in any medium or format, as long as you give appropriate credit to the original author(s) and the source, provide a link to the Creative Commons licence, and indicate if changes were made. The images or other third party material in this article are included in the article's Creative Commons licence, unless indicated otherwise in a credit line to the material. If material is not included in the article's Creative Commons licence and your intended use is not permitted by statutory regulation or exceeds the permitted use, you will need to obtain permission directly from the copyright holder. To view a copy of this licence, visit $h$ ttp://creativecommons.org/licenses/by/4.0/.

\section{SUPPLEMENTARY INFORMATION}

The online version contains supplementary material available at https://doi.org/10.1007/s11837021-05135-6.

\section{REFERENCES}

1. European Commission, Circular economy-Overview, (Eurostat 2020), https://ec.europa.eu/eurostat/web/circulareconomy. Accessed 07 June 2021.

2. European Commission, Circular Economy Action Plan. For a Cleaner and More Competitive Europe. (2020). https://ec.e uropa.eu/environment/circular-economy/pdf/new_circular_e conomy_action_plan.pdf. Accessed 07 June 2021.

3. A. Fallis, J. Chem. Inf. Model. 53, 1689 (2013).

4. R.U. Ayres, Int. Soc. Sci. J. 41, 363 (1989).

5. M.R. Chertow, Annu. Rev. Energy Environ. 25, 113 (2000).

6. G.T. Renner, Econ. Geogr. 23, 367 (1947).

7. M.R. Chertow, in Encycl. Energy, edited by C.J. Cleveland (Elsevier, Amsterdam, 2004), pp. 407-415.

8. Federacciai, L'INDUSTRIA SIDERURGICA ITALIANA (2020). http://federacciai.it/pubblicazioni-varie/. Accessed 07 December 2021. 
9. A. Primavera, L. Pontoni, D. Mombelli, S. Barella, and C. Mapelli, J. Sustain. Metall. 2, 3 (2016).

10. P. Ter Teo, S.K. Zakaria, S.Z. Salleh, M.A.A. Taib, N.M. Sharif, A.A. Seman, J.J. Mohamed, M. Yusoff, A.H. Yusoff, M. Mohamad, M.N. Masri, and S. Mamat, Metals (Basel). 10, 1 (2020).

11. M. Skaf, J.M. Manso, Á. Aragón, J.A. Fuente-Alonso, and V. Ortega-López, Resour. Conserv. Recycl. 120, 176 (2017).

12. M. Ozturk, M.B. Bankir, O.S. Bolukbasi, and U.K. Sevim, J. Build. Eng. 21, 97 (2019).

13. H. El-Didamony, A.I. Hafez, M.S. Mohammed, and R. Sabry, J. Therm. Anal. Calorim. 139, 839 (2020).

14. J.T. San-José, I. Vegas, I. Arribas, and I. Marcos, Mater. Des. 60, 612 (2014).

15. C. Pellegrino, and V. Gaddo, Cem. Concr. Compos. 31, 663 (2009).

16. I. Arribas, I. Vegas, J.T. San-José, and J.M. Manso, Mater. Des. 63, 168 (2014).

17. J.M. Manso, J.J. Gonzalez, and J.A. Polanco, J. Mater. Civ. Eng. 16, 639 (2004).

18. Y. Jiang, T.C. Ling, C. Shi, and S.Y. Pan, Resour. Conserv. Recycl. 136, 187 (2018).

19. H. Yi, G. Xu, H. Cheng, J. Wang, Y. Wan, and H. Chen, Procedia Environ. Sci. 16, 791 (2012).

20. H.Y. Poh, G.S. Ghataora, and N. Ghazireh, J. Mater. Civ. Eng. 18, 229 (2006).

21. C. Barca, D. Meyer, M. Liira, P. Drissen, Y. Comeau, Y. Andrès, and F. Chazarenc, Ecol. Eng. 68, 224 (2014).

22. C.L. Beh, T.G. Chuah, M.N. Nourouzi, and T. Choong, EJournal Chem. 9, 2557 (2012).

23. H.-S. Kim, K.-S. Kim, S.S. Jung, J.I. Hwang, J.-S. Choi, and I. Sohn, Waste Manag. 41, 85 (2015).

24. K.R. Reddy, A. Gopakumar, and J.K. Chetri, Rev. Environ. Sci. Biotechnol. 18, 127 (2019).

25. S.C. Bird, and A. Drizo, J. Environ. Sci. Heal.-Part A Toxic/ Hazardous Subst. Environ. Eng. 44, 1476 (2009).

26. G. Cornacchia, S. Agnelli, M. Gelfi, G. Ramorino, and R. Roberti, Jom 67, 1370 (2015).

27. A. Gobetti, G. Cornacchia, G. Ramorino, A. Riboldi, and L.E. Depero, Sustain. Mater. Technol. 29, e00324 (2021).

28. A. Gobetti, G. Cornacchia, and G. Ramorino, Minerals 11, 832 (2021)

29. Sottoprodotto e Cessazione Della Qualifica Di Rifiuto (La gazzetta ufficiale, 2006), https://www.gazzettaufficiale.it/at to/serie_generale/caricaArticolo?art.progressivo $=0 \&$ art.idAr ticolo $=12 \&$ art.versione $=1 \&$ art .codiceRedazionale $=010 \mathrm{G} 023$ 5\&art.dataPubblicazioneGazzetta=2010-12-10\&art.idGrup po $=0 \&$ art.idSottoArticolo1 $=10 \&$ art.idSottoArticolo=1\&art.fl agTipoArticolo=0. Accessed 15 May 2021.

30. S. Mahajan, Encyclopedia of materials: science and technology, 1st edn. (Pergamon, Oxford, 2001), pp 4476-4486.

31. G. R. Martín-Cortés, F. J. Esper, A. J. Santana de Araujo, W. T. Hennies, M. G. Silva Valenzuela, and F. R. Valenzuela-Díaz, in Charact. Miner. Met. Mater. 2015 (Springer International Publishing, London, 2016), pp. 145-152.

32. S.C. Peterson, S.R. Chandrasekaran, and B.K. Sharma, J. Elastomers Plast. 48, 305 (2016).

33. C. Li, F. Huang, J. Wang, X. Liang, S. Huang, and J. Gu, J. Polym. Eng. 38, 137 (2018).

34. P. Yuvaraj, J.R. Rao, N.N. Fathima, N. Natchimuthu, and R. Mohan, J. Clean. Prod. 170, 446 (2018).

35. Q. Wang, F. Yang, Q. Yang, J. Chen, and H. Guan, Mater. Des. 31, 1023 (2010).

36. F. El-Tantawy, and F.S. Deghaidy, Polym. Int. 49, 1371 (2000).

37. L. Dong, H. Zhang, T. Fujita, S. Ohnishi, H. Li, M. Fujii, and H. Dong, J. Clean. Prod. 59, 226 (2013).

38. L. Dong, F. Gu, T. Fujita, Y. Hayashi, and J. Gao, Energy Policy 65, 388 (2014).

39. M.T. Brown, and S. Ulgiati, J. Clean. Prod. 10, 321 (2002),

40. L. Sun, H. Li, L. Dong, K. Fang, J. Ren, Y. Geng, M. Fujii, W. Zhang, N. Zhang, and Z. Liu, Resour. Conserv. Recycl. 119, 78 (2017).
41. A. Bonoli, A.D. Esposti, and C. Magrini, Front. Mater. 7, $572955(2020)$

42. M. Svanera, S. Panza, F. Uberto, and R. Roberti, La Metall. Ital. 104, 37 (2012).

43. M. Tossavainen, F. Engstrom, Q. Yang, N. Menad, M.L. Larsson, and B. Bjorkman, Waste Manag. 27, 1335 (2007).

44. CEN EN 12457-2, CEN Standards (2002) Characterisation of waste - Leaching - Compliance test for leaching of granular waste materials and sludges-Part 2: One stage batch test at a liquid to solid ratio of $10 \mathrm{l} / \mathrm{kg}$ for materials with particle size below $4 \mathrm{~mm}$ (without or with size reduction).

45. ASTM D792, ASTM Standards (2020) Standard Test Methods for Density and Specific Gravity (Relative Density) of Plastics by Displacement.

46. ASTM D5289, ASTM Standards (2019) Standard Test Method for Rubber Property-Vulcanization Using Rotorless Cure Meters.

47. ISO 7619-1, ISO Standards (2010) Rubber, vulcanized or thermoplastic-Determination of indentation hardness-Part 1: Durometer method (Shore hardness).

48. ISO 48, ISO Standards (2018) Rubber, vulcanized or thermoplastic-Determination of hardness - Part 2: Hardness between 10 IRHD and 100 IRHD.

49. ISO 7743, ISO Standards (2011) Rubber, vulcanized or thermoplastic-Determination of compression stress-strain properties.

50. ASTM D39, ASTM Standards (2018) Standard Test Methods for Rubber Property-Compression Set.

51. F. Engström, D. Adolfsson, Q. Yang, C. Samuelsson, and B. Björkman, Steel Res. Int. 81, 362 (2010).

52. D. Mombelli, A. Gruttadauria, S. Barella, and C. Mapelli, Minerals 9, 706 (2019).

53. D.Mombelli,C.Mapelli,S.Barella,C.DiCecca,G.LeSaout, and E. Garcia-Diaz,Process Saf. Environ.Prot. 102,810(2016).

54. A. Barocci, G. Luzzari, and M. Facchin, Metall. Ital. 5, 37 (2014)

55. A. Riboldi, G. Cornacchia, M. Gelfi, L. Borgese, A. Zacco, E. Bontempi, M.V. Boniardi, A. Casaroli, and L.E. Depero, Appl. Sci. 10, 477 (2020).

56. S. Çoruh, S. Elevli, O.N. Ergun, and G. Demir, Int. J. Miner. Process. 123, 165 (2013).

57. A. Król, and K. Mizerna, Chemik 69, 670 (2015).

58. Z. Guo, L. Zhang, Y. Cheng, X. Xiao, F. Pan, and K. Jiang, Hydrometall 104, 25 (2010).

59. S.L. Meza, U. Kalbe, W. Berger, and F.-G. Simon, Waste Manag. 30, 565 (2010).

60. M.N. Satheesh Kumar and Siddaramaiah, J. Appl. Polym. Sci. 101, 2045 (2006).

61. Definizione Dei Criteri Di Ammissibilità Dei Rifiuti in Discarica (Gazzetta ufficiale n. 201, 30 Agosto 2005). https:// www.gazzettaufficiale.it/eli/gu/2005/08/30/201/sg/pdf. Accessed 15 May 2021.

62. Individuazione Dei Rifiuti Non Pericolosi Sottoposti Alle Procedure Semplificate Di Recupero Ai Sensi Degli Articoli 31 e 33 Del Decreto Legislativo 5 Febbraio 1997, n. 22. (Gazzetta ufficiale n. 115, 19 Maggio 2006). https://www.ga zzettaufficiale.it/eli/gu/2006/05/19/115/sg/pdf. Accessed 15 May 2021.

63. M.M. Salehi, T. Khalkhali, and A.A. Davoodi, Polym. Sci. Ser. A 58, 567 (2016)

64. K. Roy, M.N. Alam, S.K. Mandal, and S.C. Debnath, J. SolGel Sci. Technol. 73, 306 (2015).

65. G. Szabó, and K. Váradi, Period. Polytech Mech. Eng. 62, 148 (2018)

66. A. Wahab, and A.S. Farid, Polym. Polym. Compos. 19, 631 (2011).

67. P.F. Tuckner, Rubber World 234, 38 (2006).

68. M. Guindani, G. Ramorino, S. Agnelli, L. Conzatti, and I. Schizzi, Polym. Test. 56, 226 (2016).

Publisher's Note Springer Nature remains neutral with regard to jurisdictional claims in published maps and institutional affiliations. 